\title{
Efek Suplemen Kulit Kayu Manis dan Daun Pegagan terhadap Produktivitas Puyuh Petelur Strain Australia (Coturnix coturnix australica)
}

\section{Supplements Effects of Cinnamon Bark and Pegagan Leaf on the Productivity of Quail Eggs strains Australia (Coturnix coturnix australica)}

\author{
Sunarno \\ Departemen Biologi, Fakultas Sains dan Matematika, Universitas Diponegoro \\ Jl. Prof. Soedarto, SH, Tembalang, Semarang \\ Email: sunzen07@gmail.com
}

Diterima 4 Januari 2018 / Disetujui 30 Januari 2018

\begin{abstract}
ABSTRAK
Penelitian ini bertujuan untuk mengkaji dan menganalisa pengaruh suplemen dari kulit kayu manis dan daun pegagan terhadap bobot dan jumlah telur serta produktivitas puyuh. Metode yang digunakan dalam penelitian ini adalah rancangan acak lengkap yang terdiri atas 8 perlakuan dengan 3x ulangan. Delapan perlakuan tersebut, meliputi kontrol (pakan tanpa pemberian suplemen tepung kulit kayu manis dan daun pegagan), pakan yang diberi suplemen tepung kulit kayu manis $5 \%$ atau $10 \%$, pakan yang diberi suplemen tepung daun pegagan $5 \%$ atau 10\%, pakan yang diberi suplemen tepung kulit kayu manis dan pegagan (5\%:5\%, 5\%:10\% atau 10\%:5\%). Pemberian perlakuan di lakukan secara ad libitum setiap hari sebanyak 2 kali. Perlakuan pakan bersuplemen terhadap hewan uji diberikan selama 30 hari. Hasil penelitian menunjukkan bahwa suplemen tepung kulit kayu manis dan daun pegagan dalam pakan dapat meningkatkan bobot tubuh, bobot telur, namun menurunkan jumlah dan produktivitas telur. Kesimpulan dari penelitian ini adalah, suplemen dari kulit kayu manis dengan konsentrasi 5\% atau kombinasi suplemen dari kulit kayu manis-daun pegagan dengan rasio 5\%:10\% dapat meningkatkan produktivitas puyuh.
\end{abstract}

Kata kunci: telur puyuh, kayu manis, pegagan, suplemen, kolesterol, antioksidan

\begin{abstract}
This research aims to examine and analyze the effects of supplements from cinnamon bark and pegagan leaf against the weight and number of eggs and quail productivity. The method used in this study was a complete randomized design consisting of eight treatments with three replications. Eight such treatments, including controls (feed without supplements from cinnamon bark and pegagan leaf), feed that has been given a supplement of cinnamon bark $5 \%$ or $10 \%$, feed that has been given a supplement of pegagan leaf $5 \%$ or $10 \%$, feed that has been given a combination of supplements from cinnamon bark and pegagan leaf (5\%:5\%, 5\%:10\% or 10\%:5\%). Treatment was administered ad libitum twice daily. The supplement feeding treatment of test animals has been given for 30 days. The results showed that supplementation of flour from cinnamon bark dan pegagan leaf in the feed can increase body weight, egg weight, but decrease the amount or productivity of egg. The conclusions that has been obtained from this research are that supplements of cinnamon with 5\% concentration or combination of supplements of cinnamon bark and pegagan leaf with a concentration ratio of 5\%:10\% has been able to increase quail productivity.
\end{abstract}

Keywords: quail eggs, cinnamon bark, pegagan leaf, supplement, cholesterol, antioxsidants

\section{PENDAHULUAN}

Puyuh (Coturnix coturnix) merupakan salah satu unggas yang banyak dikembangkan oleh peternak di Indonesia Akhir-akhir ini konsumsi masyarakat terhadap protein hewani terus mengalami peningkatan. Berdasarkan data dari Dirjen Peternakan dan Kesehatan Hewan (2012) menunjukkan bahwa konsumsi telur puyuh per hari oleh masyarakat antara tahun 2009 sampai 2011 terus menunjukkan peningkatan yang sangat nyata, 
secara berurutan dari $0,040 \mathrm{~kg}$, menjadi $0,043 \mathrm{~kg}$, dan akhirnya $0,052 \mathrm{~kg}$. Ketersediaan telur puyuh tersebut sangat erat kaitannya dengan keberadaan populasi puyuh Coturnix coturnix di Indonesia dengan tingkat produktivitas yang cukup tinggi. Tahun 2010 sampai 2012, populasi puyuh terus menunjukkan peningkatan, yaitu secara berurutan dari 7,054 juta menjadi 7,357 juta ekor dan akhirnya 7,841 juta ekor. Jenis unggas ini dapat berproduksi, menghasilkan telur mencapai 200-300 butir/ekor/tahun (Nugroho dan Mayun, 1986). Kondisi manajemen pemeliharaan budidaya puyuh yang tidak higienis, kepadatan populasi puyuh dalam kandang, dan berbagai macam faktor stres dari lingkungan dapat menjadi pemicu terjadinya penurunan produktivitas puyuh.

Penurunan produktivitas puyuh dapat diketahui dari tingkat produksi dan bobot telur. Kedua variabel ini biasanya dipicu karena adanya penurunan bobot tubuh yang diakibatkan oleh penurunan konsumsi pakan, stres lingkungan, maupun komposisi nutrisi dalam pakan yang tidak seimbang (Saki et al., 2012). Abidin and Khatoon (2013) menyatakan bahwa cekaman panas dan kelembapan lingkungan yang tinggi dapat menyebabkan inefisiensi penggunaan energi oleh ternak sehingga tidak tersedia energi yang cukup untuk mendukung produksi yang normal. Bagh (2016) menyatakan stres dapat menurunkan efisiensi dari pencernaan, absorbsi, transportasi nutrien yang berakibat pada penurunan produksi dan bobot telur.

Selain berbagai macam faktor yang menyebabkan penurunan produktivitas puyuh, ada beberapa hasil penelitian yang menyatakan bahwa produktivitas puyuh dapat ditingkatkan salah satunya dengan pemberian suplemen dalam pakan. Subekti (2005) menyatakan, produktivitas puyuh dapat ditingkatkan melalui pemberian suplemen vitamin $\mathrm{C}$ sebanyak 150 dan $300 \mathrm{mg} / \mathrm{kg}$. Vitamin C telah diketahui mempunyai peran penting di dalam tubuh, baik sebagai antioksidan maupun menunjang proses metabolisme. Oleh karena itu pemberian suplemen dalam pakan yang memiliki fungsi sebagai antioksidan dan mendukung proses metabolisme penting untuk dilakukan guna meningkatkan produktivitas puyuh. Bahan yang dapat digunakan sebagai suplemen pakan diketahui banyak berasal dari jenis-jenis tanaman herbal, seperti kayu manis
(Cinnamomum sp) dan pegagan (Centella asiatica).

Kayu manis merupakan salah satu tanaman herbal yang sudah banyak dimanfaatkan oleh masyarakat di Indonesia, baik sebagai penambah cita rasa makanan atau minuman maupun sebagai obat tradisional. Shah dan Panchal (2010) menyatakan bahwa kulit kayu manis mengandung antioksidan polifenol yang bermanfaat untuk kesehatan, meningkatkan produktivitas, memperbaiki jaringan akibat penyakit metabolik, maupun memperlambat penurunan fungsi organ akibat faktor bertambahnya umur. Polifenol dalam kulit kayu manis terdiri atas rutin, katekin, kuarsetin, kaempferol, isorhamnetin, berturut-turut dengan persentase $90,1 \%, 1,9 \%, 0,2 \%, 0,02 \%$, $0,02 \%$, dan $0,103 \%$. Polifenol juga memiliki potensi dapat mengefektifkan proses metabolisme dalam tubuh yang penting dalam meningkatkan produktivitas. Jenis antioksidan ini telah diketahui terlibat dalam peningkatan síntesis protein-protein yang berperan dalam peningkatan biomassa sel (Ravindran et al., 2004).

Pegagan atau $C$. asiatica memiliki banyak manfaat, selain dapat meningkatkan kandungan antioksidan di dalam tubuh juga memiliki fungsi dalam mendukung aktivitas metabolisme. Penelitian yang dilakukan oleh Pitella et al (2009) menyatakan, ekstrak C. asiatica mampu meningkatkan produktivitas. Hasil penelitian Annisa (2006) menunjukkan bahwa dalam daun pegagan terkandung berbagai macam senyawa aktif, yang meliputi asiaticoside, asiatic acid, madecassoside, madecassic acid dan brahmoside. Januwati dan Yusron (2005) menyatakan, C. asiatica banyak memiliki kandungan minyak atsiri, antara lain sitronelal, linalool, neral, menthol dan linalil asetat. Berbagai macam senyawa tersebut sangat bermanfaat untuk menunjang produktivitas hewan ternak.

Berdasarkan permasalahan yang berkaitan dengan produktivitas puyuh peterlur, potensi dan bukti hasil penelitian manfaat kulit kayu manis dan daun pegagan perlu dilakukan pengembangan penelitian untuk memecahkan permasalahan tersebut. Oleh karena itu penelitian ini dengan memanfaatkan kedua bahan tersebut sebagai suplemen pakan dan akan didibuktikan pengaruhnya terhadap tingkat produktivitas puyuh petelur melalui variabel bobot 
tubuh, jumlah dan bobot telur yang dihasilkan.

\section{METODE PENELITIAN}

\section{Hewan Uji}

Hewan uji yang digunakan dalam penelitian ini adalah puyuh strain Australia (Coturnix coturnix australica). Penelitian ini terdiri atas 8 perlakuan dengan 3 kali ulangan sehingga jumlah hewan uji yang digunakan berjumlah 24 ekor. Hewan uji diambil dari lokasi peternakan berumur 7 hari selanjutnya dipelihara dalam kandang kolektif selama 7 hari, dilanjutkan aklimasi dalam kandang baterai selama 7 hari dan diberi perlakuan selama 30 hari.

\section{Prosedur Penelitian}

Penelitian diawali dengan tahap koleksi, pengeringan dan pembuatan tepung dari kulit kayu manis dan daun pegagan. Bagian kulit kayu manis dan daun pegagan dikoleksi dari wilayah Semarang. Bahan-bahan tersebut kemudian dipotong-potong sekitar $3 \mathrm{~cm}$, dicuci, ditiriskan, dan dikeringkan anginkan di bawah sinar matahari selama 72 jam atau dikeringkan dengan oven pada temperatur antara $40-60^{\circ} \mathrm{C}$ selama $30-36$ jam sampai diperoleh bahan kering dengan kadar air $10 \%$. Kulit kayu manis atau daun pegagan kering kemudian dihancurkan dengan grinder sampai diperoleh tepung. Tepung disimpan di dalam boks plastik dan siap untuk digunakan.

Tahap selanjutnya adalah pembuatan pakan bersuplemen tepung kulit kayu manis dan daun pegagan. Pakan standar bersuplemen untuk puyuh dibuat dengan cara menambahkan tepung dari kedua bahan tersebut (baik secara terpisah/kombinasi) ke dalam pakan standar puyuh sesuai persentase yang dibutuhkan. Pakan yang telah tercampur dengan bahan suplemen kemudian diaduk-aduk sampai homogen, dimasukkan ke dalam tempat pakan. Pakan bersuplemen diberikan secara ad libitum setiap pagi jam 07.00 dan sore jam 16.00. Tahap penelitian dilanjutkan dengan penyiapan kandang puyuh. Kandang puyuh (baterai) yang digunakan memiliki panjang $80 \mathrm{~cm}$ dan lebar $60 \mathrm{~cm}$. Populasi puyuh dalam kandang berjumlah 24 ekor. Kandang puyuh diberi pencahayaan yang cukup dan dirawat dengan baik dengan membersihkan kandang secara rutin.

Hewan uji yang digunakan adalah puyuh (Coturnix coturnix australica) yang telah berumur 42 hari (masak kelamin). Pemilihan hewan uji dilakukan dengan memilih bibit yang baik, bebas penyakit, dan normal. Aklimasi hewan uji dilakukan selama 7 hari dalam kandang individu. Selama aklimasi, hewan uji diberi pakan dan minum secara ad libitum dan dilakukan pemeliharaan kesehatan, seperti pemeriksaan rutin, penambahan vitamin dan vaksinasi.

Hewan uji yang sudah diaklimasi kemudian diberi perlakuan. Pakan bersuplemen tepung kulit kayu manis dan daun pegagan diberikan pada puyuh setelah aklimasi yaitu pada umur 15 hari selama 36 hari. Ada delapan perlakuan yang diberikan pada hewan uji, meliputi P0 yaitu kontrol (pakan standar tanpa pemberian suplemen tepung kulit kayu manis dan daun pegagan), P1 dan P2 yaitu pakan dengan suplemen tepung kulit kayu manis 5\% dan 10\%, P3 dan P4 adalah pakan dengan suplemen tepung daun pegagan $5 \%$ dan $10 \%$, P5, P6, dan P7 adalah pakan dengan kombinasi suplemen tepung kulit kayu manis dan pegagan, berturut-turut (5\%:5\%, 5\%:10\% atau 10\%:5\%). Pakan dengan tambahan suplemen diberikan secara ad libitum $2 \mathrm{x}$ sehari yaitu pagi jam 07.00 dan sore jam16.00. Pengukuran temperatur dan kelembapan ruangan selama berlangsungnya penelitian dilakukan setiap hari. Di akhir perlakuan dilakukan penimbangan bobot tubuh puyuh. Pengumpulan telur dilakukan setiap hari yang dilanjutkan dengan penimbangan menggunakan timbangan digital. Pengukuran kadar kolesterol kuning telur dilakukan dengan metode yang dilakukan oleh Ariyani (2006), sedangkan kadar antioksidan dengan metode yang dilakukan oleh Nahariah et al. (2014).

\section{Analisis dan Interpretasi Data}

Data yang diperoleh, meliputi bobot tubuh akhir, produktivitas telur, kandungan antioksidan dan kolesterol dalam kuning telur puyuh diuji pola distribusi dan homogenitasnya, dan dilanjutkan dengan uji Analysis of Varian (ANOVA) yang dilanjutkan dengan Duncant Multi Range Test 
(DMRT), masing-masing dengan taraf kepercayaan $95 \%$.

\section{HASIL DAN PEMBAHASAN}

Data hasil penelitian yang meliputi bobot tubuh akhir, jumlah dan produktivitas telur, dan bobot telur puyuh strain Australia di sajikan pada Tabel 1. Berdasarkan data pada Tabel 1 tersebut menunjukkan bahwa suplemen tepung kayu manis (Cinnamomum sp) dan pegagan (Centella asiatica) yang diberikan dalam pakan memberi pengaruh terhadap beberapa parameter yang diamati. Hasil penelitian berupa bobot tubuh tikus menunjukkan bahwa perlakuan P6 (kombinasi tepung kayu manis-pegagan dengan rasio 5\%:10\%) memberi pengaruh terhadap nilai bobot tubuh tikus paling tinggi yaitu $0,17 \mathrm{~kg}$, berbeda nyata dengan perlakuan P1, P2, P3, P5, dan P7 namun tidak berbeda nyata dengan kontrol dan P4. Bobot tubuh tikus paling rendah terdapat pada perlakuan P5 yaitu sebesar 0,12 kg. Kombinasi suplemen tepung kayu manis dengan pegagan mempunyai peran penting terhadap proses metabolisme tubuh, baik yang berorientasi pada penurunan atau peningkatan produktivitas hewan.

Tabel 1. Parameter kuantitatif puyuh petelur setelah perlakuan pakan dengan suplementasi tepung kulit kayu manis dan daun pegagan

\begin{tabular}{lcccccccc}
\hline \multirow{2}{*}{\multicolumn{1}{c}{ Parameter }} & \multicolumn{9}{c}{ Perlakuan } \\
\cline { 2 - 8 } & P0 & P1 & P2 & P3 & P4 & P5 & P6 & P7 \\
\hline Bobot tubuh akhir (kg) & $0.16^{\mathrm{ab}}$ & $0.15^{\mathrm{a}}$ & $0.15^{\mathrm{a}}$ & $0.15^{\mathrm{a}}$ & $0.16^{\mathrm{ab}}$ & $0.12^{\mathrm{c}}$ & $0.17^{\mathrm{b}}$ & $0.15^{\mathrm{a}}$ \\
Bobot telur (g) & $9.57^{\mathrm{b}}$ & $10.41^{\mathrm{c}}$ & $9.84^{\mathrm{b}}$ & $8.51^{\mathrm{a}}$ & $9.60^{\mathrm{b}}$ & $10.58^{\mathrm{cd}}$ & $11.33^{\mathrm{d}}$ & $10.37^{\mathrm{c}}$ \\
Jumlah telur & $27.00^{\mathrm{c}}$ & $30.00^{\mathrm{c}}$ & $11.00^{\mathrm{b}}$ & $24.00^{\mathrm{c}}$ & $17.00^{\mathrm{b}}$ & $8.00^{\mathrm{a}}$ & $16.00^{\mathrm{b}}$ & $8.00^{\mathrm{a}}$ \\
Produktivitas telur (\%) & $90.00^{\mathrm{c}}$ & $100^{\mathrm{c}}$ & $36.67^{\mathrm{b}}$ & $80.00^{\mathrm{c}}$ & $56.67^{\mathrm{b}}$ & $26.67^{\mathrm{a}}$ & $53.33^{\mathrm{b}}$ & $26.67^{\mathrm{a}}$ \\
\hline
\end{tabular}

Keterangan: P0: kontrol (pakan tanpa suplementasi tepung kulit kayu manis dan daun pegagan), P1 dan P2, pakan dengan suplementasi tepung kayu manis 5\% dan 10\%, P3 dan P4, pakan dengan suplementasi tepung pegagan $5 \%$ dan $10 \%, \mathrm{P} 5, \mathrm{P} 6$, dan $\mathrm{P} 7$, pakan dengan suplementasi tepung kayu manis dan pegagan dengan rasio $(5 \% ; 5 \%),(5 \%: 10 \%)$, dan $(10 \%: 5 \%)$

Komposisi bahan aktif dari kombinasi kedua suplemen tersebut juga sangat menentukan arah proses metabolisme. Perlakuan P6 (kayu manis-pegagan dengan rasio 5\%;10\%) memberi pengaruh terhadap produktivitas yang ditunjukkan dengan bobot tubuh akhir hewan uji paling tinggi. Hal ini berarti bahan-bahan aktif dari kedua bahan tersebut berada pada komposisi yang tepat yang bekerja saling bersinergi dalam meningkatkan aktivitas metabolisme tubuh yang mengarah terhadap produktivitas puyuh. Bahan aktif dari tepung pegagan yang bekerja lebih dominan diduga terlibat dalam mengefektifkan proses metabolisme. Sebaliknya pada perlakuan P5 (kayu manis-pegagan dengan rasio 5\%:5\%) memberi pengaruh terhadap produktivitas paling rendah. Bahan aktif dari kedua suplemen yang bekerja lebih dominan diduga memperlambat proses metabolisme. Gangguan terhadap proses metabolisme berdampak pada penurunan produksi energi dan produktivitas (Rao et al., 2005; Ravindran et al., 2004).

Ravindran et al. (2004) menyatakan, senyawa polifenol dalam kayu manis diduga terlibat dalam peningkatan sintesis protein di dalam tubuh. Kadar protein yang meningkat, baik protein enzimatis atau non enzimatis dapat meningkatkan laju metabolisme, pertumbuhan, dan produktivitas. Annisa (2006) menyatakan, ekstrak air daun pegagan dapat meningkatkan kadar neurotransmiter, seperti dopamin, norepinefrin, epinefrin dan serotonin yang memiliki efek meningkatkan proses katabolisme. Proses ini akhirnya akan menghasilkan energi metabolisme yang tinggi yang dapat digunakan untuk peningkatan produktivitas yang ditunjukkan oleh peningkatan bobot tubuh puyuh. Ekstrak daun pegagan juga dapat meningkatkan status hematologis darah yaitu hemoglobin dan hematokrit. Hemoglobin dan nilai hematokrit yang 
meningkat memiliki korelasi dengan banyaknya oksigen yang ditransportasikan ke dalam jaringan. Nutrisi dan oksigen yang banyak akan meningkatkan proses metabolisme dan produktivitas hewan uji (Rahmasari, 2006).

Bobot tubuh puyuh yang rendah pada perlakuan P5 (suplemen kombinasi tepung kulit kayu manis-pegagan dengan rasio 5\%:5\%) diduga disebabkan oleh bahan aktif dalam tepung pegagan yang bersifat narkotis. Peng et al (2008) menyatakan, bahan aktif yang bersifat narkotis dalam jumlah yang berlebihan dapat memicu terjadinya hipoksia. Kondisi ini dapat menimbulkan stres oksidatif yang mengarah terjadinya gangguan metabolisme, penurunan produksi energi dan bobot tubuh. Bobot tubuh hewan uji yang rendah diduga juga terkait dengan hambatan penyerapan kolesterol, asam lemak, dan trigliserida dalam saluran pencernaan karena peran bahan aktif dari kayu manis dan pegagan yang membentuk senyawa kompleks dalam saluran pencernaan. Absorbsi hasil-hasil pencernaan yang rendah menyebabkan ketersediaan substrat metabolisme yang rendah dan berdampak pada penurunan metabolisme, produksi energi, dan bobot tubuh hewan uji seperti pada perlakuan P5 (Rao et al., 2005; Ravindran et al., 2004).

Bobot tubuh mempunyai keterkaitan erat dengan bobot telur. Puyuh dengan bobot tubuh yang berat cenderung menghasilkan telur yang lebih berat (Tabel 1). Bobot telur puyuh paling berat terdapat pada perlakuan P6 (kayu manispegagan dengan rasio 5\%:10\%), berbeda nyata dengan kontrol dan perlakuan lainnya. Bobot telur puyuh paling rendah terdapat pada perlakuan P3 (suplemen pegagan 5\%) yang juga berbeda nyata dengan kontrol. Bobot telur puyuh pada perlakuan P1, P5, dan P7 tidak berbeda nyata satu dengan lainnya namun berbeda nyata dengan kontrol dan perlakuan P2, P3, dan P4. Suplemen tepung kayu manis dan pegagan pada rasio 5\%:10\% memberi pengaruh efektif, tidak hanya terhadap bobot tubuh namun juga terhadap bobot telur. Puyuh dengan bobot tubuh yang berat akan memiliki berat telur yang lebih berat. Bukti ini menunjukkan bahwa produk energi dan síntesis protein dapat ditingkatkan oleh bahan aktif dari suplemen yang diberikan. Bahan aktif dalam suplemen dapat memicu síntesis vitelogenin dan kinerja reproduksi puyuh sehingga proses pembentukan telur terjadi lebih optimal. Rahmasari (2006) dan Ravindran et al. (2004) menyatakan, senyawa polifenol dalam pegagan dan kayu manis dapat memelihara homeostasis, meningkatkan proses metabolisme dan produksi energi. Senyawa polifenol dapat meningkatkan síntesis protein. Akibatnya, síntesis vitelogenin dalam hati yang merupakan bahan pembentuk kuning telur akan meningkat, kinerja reproduksi akan meningkat sehingga akan dihasilkan telur dengan bobot yang lebih berat.

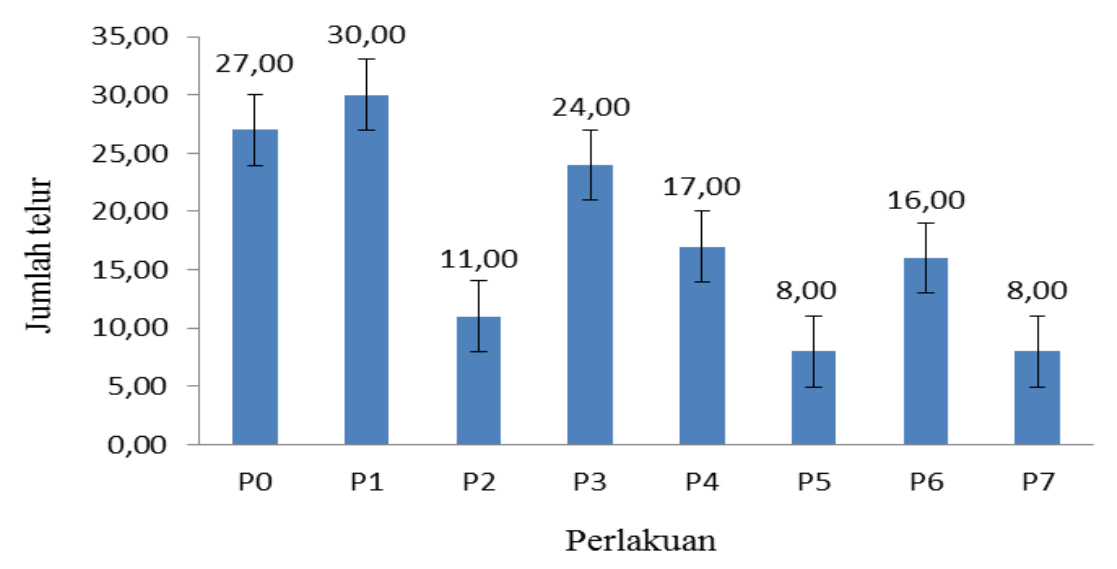

Gambar 1. Jumlah telur puyuh setelah perlakuan pakan dengan suplementasi tepung kulit kayu manis dan daun pegagan 

Bobot telur yang rendah seperti pada perlakuan P3 (suplemen pegagan 5\%) memiliki keterkaitan dengan tersedianya substrat untuk síntesis vitelogenin dan kinerja reproduksi yang tidak optimal. Hal ini dapat disebabkan karena keberadaan bahan bioaktif dalam suplemen pegagan bersifat narkotis yang berpotensi menyebabkan gangguan penyediaan substrat metabolisme. Ketersediaan substrat yang rendah berdampak pada produk metabolisme yang rendah yang akhirnya berpengaruh terhadap kinerja reproduksi dan proses pembentukan telur yang tidak optimal. Hal ini akhirnya akan berpengaruh terhadap bobot telur puyuh dengan berat yang lebih rendah dibanding perlakuan lainnya (Rao et al., 2005). Bobot tubuh dan telur yang tinggi karena pengaruh suplemen tepung kayu manis dan pegagan tidak selalu berkorelasi positif dengan jumlah telur yang dihasilkan. Hasil penelitian seperti pada Gambar 1 dan 2 menunjukkan bahwa perlakuan P5 dan P7 (kayu manis-pegagan dengan rasio 5\%:5\%; 10\%:5\%) memberi pengaruh terhadap jumlah telur puyuh yang paling rendah dibanding perlakuan lainnya. Jumlah telur paling tinggi terdapat pada perlakuan P1 (kayu manis $5 \%$ ), berbeda nyata dengan perlakuan P2, P4, P5, P6, dan P7 namun tidak berbeda nyata dengan kontrol dan P3.

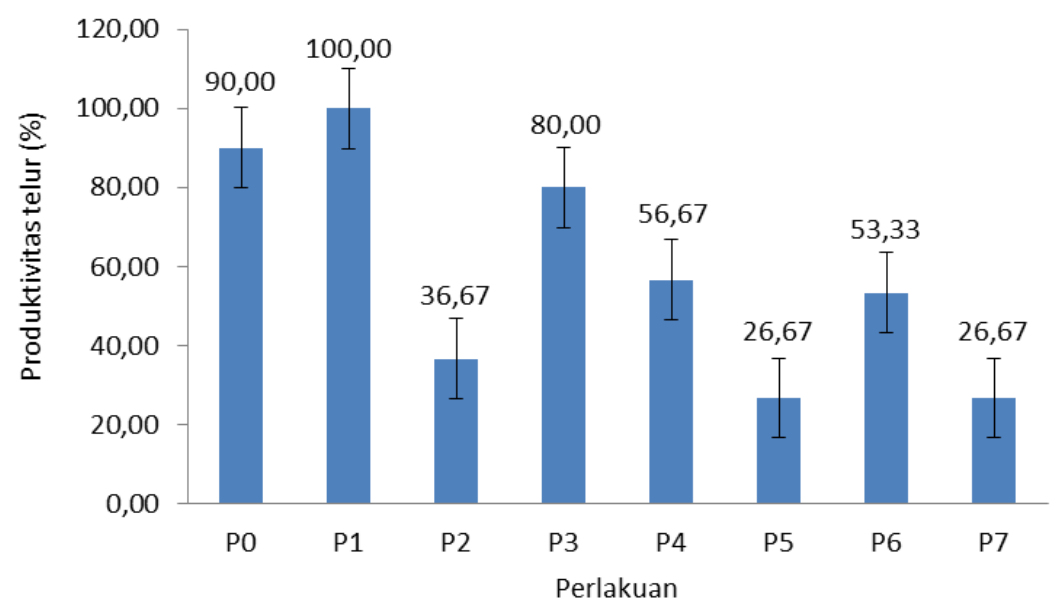

Gambar 2. Produktivitas telur puyuh setelah perlakuan pakan dengan suplementasi tepung kulit kayu manis dan daun pegagan

Bahan aktif dari suplemen, baik kayu manis maupun pegagan memiliki keterkaitan erat dengan bobot tubuh dan bobot telur, serta produktivitas puyuh. Hasil penelitian ini memberi bukti bahwa suplemen dari kedua bahan tersebut dapat meningkatkan sintesis protein, substrat metabolisme dan kinerja reproduksi namun dengan waktu yang lama. Kedua suplemen tersebut diketahui memperlambat proses pembentukan telur sehingga proses pembentukan telur mengalami penundaaan. Kondisi ini akhirnya berpengaruh terhadap jumlah telur yang dihasilkan oleh puyuh juga lebih sedikit. Perlakuan P1 dan P3 (suplemen kayu manis 5\%; pegagan 5\%) dapat meningkatkan jumlah telur puyuh. Bahan aktif dari kedua suplemen tersebut bekerja secara optimal selama di dalam tubuh puyuh sehingga tidak hanya berpengaruh terhadap penyediaan substrat metabolisme, protein dan energi namun juga mendukung proses pembentukan telur yang lebih cepat. Kondisi ini akhirnya berpengaruh terhadap peningkatan jumlah dan produktivitas puyuh petelur. Bukti ini sejalan dengan bukti penelitian yang dilakukan oleh Rahmasari (2006) dan Ravindran et al. (2004) tentang peran beberapa bahan aktif dari kedua suplemen tersebut.

\section{KESIMPULAN}

Suplemen tepung kulit kayu manis dan daun pegagan dalam pakan berpengaruh nyata terhadap bobot tubuh, bobot telur, dan jumlah/produktivitas telur pada puyuh strain Australia. Suplemen tepung kulit kayu manis dalam pakan dengan 
konsentrasi 5\% atau kombinasi tepung kulit kayu manis-daun pegagan dengan rasio 5\%:10\% memberi pengaruh terbaik terhadap beberapa parameter yang diamati.

\section{DAFTAR PUSTAKA}

Abidin, Z and A. Khatoon. 2013. Heat stress in poultry and the beneficial effects of ascorbic acid (vitamin C) supplementation during periods of heat stress. World's Poultry Science Association, 69(1): 135-152

Annisa, RF. 2006. Pengaruh pemberian ekstrak air daun pegagan (Centella asiatica) terhadap kemampuan kognitif dan kadar neurotransmiter monoamin pada hipokampus tikus (Rattus norvegicus L) galur Wistar jantan dewasa. Skripsi Sarjana Biologi, Institut Teknologi Bandung, Bandung

Ariyani, E. 2006. Penetapan kandungan kolesterol dalam kuning telur pada ayam petelur. Balai Penelitian Ternak, Pusat Penelitian dan Pengembangan Peternakan., pp. 12-15

Bagh, J. 2016. Body weight, egg production, and egg quality traits of gray, brown, and white varieties of Japanese quail (Coturnix coturnix japonica) in coastal climatic condition of Odisha. World Poult Sci J., 46: 219-234

Dirjen Peternakan dan Kesehatan Hewan. 2012. Buku statistik peternakan 2012. Dinas Peternakan dan Kesehatan Hewan. Propinsi Lampung

Januwati, M dan M. Yusron. 2005. Budidaya tanaman pegagan. balai penelitian tanaman obat dan aromatika, Badan Penelitian dan Pengembangan Pertanian. Jakarta

Nugroho dan I. G. K. Mayun. 1986. Beternak Burung Puyuh. Penerbit Eka Offset, Semarang.

Peng, K., Cheng, W and J. Ma. 2008. Cinnamon bark proanthocyanidins as reactive carbonyl scavengers to prevent the formation of advanced glycation endproducts. Journal of Agricultural and Food Chemistry, 56(6): 1907-1911.

Pittella, F., Dutra, R.C., Junior, D.D., Lopes, M.T. and Barbosa, N.R. 2009. Antioxidant and cytotoxic activities of Centella asiatica (L) Urb. Int J Mol Sci, 10(9), 3713-21.

Rahmasari, N. 2006. Pengaruh ekstrak air daun pegagan (Centella asiatica) terhadap kemampuan belajar dan mengingat, kadar hemoglobin dan nilai hematokrit pada tikus jantan (Rattus norvegicus L) galur Wistar dewasa. Skripsi Sarjana Biologi, Institut Teknologi Bandung, Bandung.

Rao, S. B., Chetana, M and U. P. Devi. 2005. Centella asiatica treatment during postnatal periode enhances learning and memory in mice. Physiology and Behaviour, 86: 449457.

Ravindran, P. N., Nirmal, B. K and M. Shylaja. 2004. Cinnamon and Cassia the genus Cinnamomum: medicinal and aromatic plants-industrial profiles. CRC Press, Washington. D. C, USA.

Saki, A., Abbasinezhad, M., Ghazi, S., Tabatabai, M., Ahamdi, A and K. Zaboli. 2012. Intestinal characteristics, alkaline phosphatase and broilers performance in response to extracted and mechanical soybean meal replaced by fish meal. J Agric Sci Technol., 14: 105-114

Shah, M and Panchal M. 2010. Ethnopharmacological properties of Cinnamomum tamala. Inter. $J$. Pharmaceutical Sciences Review and Research, 5(3): 141-144.

Subekti, E. 2005. Pengaruh kombinasi suplementasi vitamin $\mathrm{C}$ dan vitamin $\mathrm{E}$ sintetis terhadap produksi dan daya tetas telur puyuh. Jurnal Ilmu-Ilmu Pertanian, $1(2): 45-57$ 